\title{
Poland's economic relations with Kazakhstan
}

Wazakhstan is among the most rapidly developing countries in Central Asia. It has the
ninth largest area in the world -2.725 million $\mathrm{km}^{2}$, which is more than 8,5 times bigger than Poland. In 2019, Kazakhstan was inhabited by more than 18.5 million people. It boasts abundant natural resources. Around $30 \%$ of the global chromium and $25 \%$ of uranium is produced in Kazakhstan. One of the priorities of Kazakhstan's development strategy until 2030 is to maintain a stable economic growth, based on the open market economy principles. Oil is the country's most important raw material. In the World Bank's 2019 global ranking Kazakhstan ranked 28th in terms of ease of investment and doing business. ${ }^{247}$ The top sectors of the economy contributing to the GDP in 2019 were: industry $-33.05 \%$; services $-55.47 \%$; agriculture $-4.44 \%{ }^{248}$.

The aim of this study is to show Poland's position in the economic relations with Kazakhstan. The research hypothesis is as follows: While many agreements have been signed by Poland and Kazakhstan, their implementation has been very limited.

To test this hypothesis, the author framed the following research questions:

1/ What economic agreements have been concluded between Kazakhstan and Poland?

2/ What was the size of trade and foreign investments between Poland and Kazakhstan over the period investigated?

3/ What were the results of the efforts of the Polish-Kazakh Intergovernmental Commission for Economic Cooperation?

The study is based on statistical material of the World Bank, the Polish Central Statistical Office (GUS), and Polish and Russian literature.

\footnotetext{
247 Kazakhstan Among Word Top 30 Economics in Ease of Doing Business za: https:/www.worldbank.org/en/news/press-release/2018/10/31/kazakhstan-among-worlds-top-30-economies-inease-of-doing-business (10.11.2020)

${ }^{248}$ GDP - composition by sector of origin, za: https://www.statista.com/statistics/436156/share-of-economicsectors-in-the-gdp-in-kazakhstan/ (10.11.2020).
} 


\section{Basic macroeconomic data}

The basic indicators of the rapidly developing economy of Kazakhstan are presented in Table 1.

Table 1 The basic macroeconomic indicators of Kazakhstan in 1992-2019.

\begin{tabular}{|c|c|c|c|c|c|c|}
\hline Year & $\begin{array}{l}\text { GDP* (in } \\
\text { million } \\
\text { USD) }\end{array}$ & $\begin{array}{l}\text { Per capita } \\
\text { GDP (USD) }\end{array}$ & $\begin{array}{l}\text { Exports* } \\
\text { (in million } \\
\text { USD) }\end{array}$ & $\begin{array}{l}\text { Imports } \\
\text { (in million } \\
\text { USD) }\end{array}$ & $\begin{array}{l}\text { FDI inflow } \\
\text { (in million } \\
\text { USD) }\end{array}$ & $\begin{array}{l}\text { FDI outflow } \\
\text { (in million } \\
\text { USD) }\end{array}$ \\
\hline 1992 & 26,477 & 7,196 & 3,245 & 3,967 & 100.0 & - \\
\hline 1993 & 24,603 & 6,748 & 3,277 & 3,887 & $1,271.4$ & - \\
\hline 1994 & 21,968 & 6,444 & 3,231 & 3,561 & 659.7 & 0 \\
\hline 1995 & 20,555 & 6,087 & 5,250 & 3,807 & 964.3 & 0 \\
\hline 1996 & 21,035 & 6,308 & 5,911 & 4,241 & $1,136.9$ & 0 \\
\hline 1997 & 22,166 & 6,651 & 6,497 & 4,301 & $1,321.9$ & 1 \\
\hline 1998 & 22,135 & 6,698 & 5,334 & 4,314 & $1,160.9$ & 8 \\
\hline 1999 & 16,871 & 7,009 & 5,872 & 3,655 & $1,437.7$ & 4 \\
\hline 2000 & 18,292 & 7,890 & 8,812 & 5,040 & $1,282.5$ & 4 \\
\hline 2001 & 22,153 & 9,168 & 8,639 & 6,446 & $2,835.0$ & -26 \\
\hline 2002 & 24,637 & 10,211 & 9,670 & 6,584 & $2,590.2$ & 426 \\
\hline 2003 & 30,834 & 11,318 & 12,927 & 8,409 & $2,092.0$ & -121 \\
\hline 2004 & 43,152 & 12,642 & 20,093 & 12,781 & $4,157.2$ & $-1,279$ \\
\hline 2005 & 57,124 & 14,178 & 27,849 & 17,353 & $1,971.2$ & -148 \\
\hline 2006 & 81,004 & 15,881 & 38,250 & 23,677 & $6,278.2$ & -411 \\
\hline 2007 & 104,850 & 17,667 & 47,755 & 32,756 & $11,119.0$ & 3,089 \\
\hline 2008 & 133,442 & 18,140 & 71,172 & 37,889 & $14,321.8$ & 1,207 \\
\hline 2009 & 115,309 & 18,245 & 43,196 & 28,409 & $13,242.5$ & 3,159 \\
\hline 2010 & 148,047 & 19,530 & 59,971 & 31,107 & $11,550.7$ & 7,885 \\
\hline 2011 & 192,626 & 21,129 & 84,336 & 36,906 & $13,973.1$ & 5,390 \\
\hline 2012 & 207,999 & 22,276 & 86,449 & 46,358 & $13,337.0$ & 1,481 \\
\hline 2013 & 236,635 & 23,644 & 84,699 & 48,806 & $10,321.0$ & 2,287 \\
\hline 2014 & 221,416 & 24,734 & 79,459 & 41,296 & $8,405.9$ & 3,815 \\
\hline 2015 & 181,754 & 24,940 & 45,954 & 30,568 & $4,012.1$ & 889 \\
\hline 2016 & 135,276 & 25,167 & 36,775 & 25,377 & $8,569.3$ & $-5,367$ \\
\hline 2017 & 128,825 & 25,252 & 48,502 & 29,559 & $4,669.0$ & 913 \\
\hline 2018 & 136,304 & 26,147 & 61,109 & 33,654 & $3,817.0$ & $-1,103$ \\
\hline 2019 & 170,326 & 27,443 & 57,309 & 37,757 & $3,118.0$ & 3,588 \\
\hline
\end{tabular}

Source: own elaboration based on UNCTAD data, http://unctad.org/en/Pages/statistics.aspx (14.11.2020)*GDP and GDP per capita in current prices.

The figures in Table 1 show that Kazakhstan's GDP was steadily increasing, as was the GDP per capita. The balance of trade was negative before 1994 but thereafter remained positive for the rest of the period considered. The main sectors of Kazakhstan's economy with export potential are: 1/ Extraction and processing of oil and natural gas; 2/ Extraction and processing of non-ferrous metals; 3/ Development of machinery industry; 4/ Agriculture and food processing; 4/ Modernisation of road and rail infrastructure; 5/ Construction; 6/ Pharmaceutical industry. Kazakhstan's main trading partners were the member states of the European Union (around $40 \%$ of total trade). In the $2010 \mathrm{~s}$, the main importers of 
Kazakhstan's raw materials were: Italy, China, Netherlands and Russia, whereas the sources of Kazakhstan's imports were: Russia, China, Germany and Italy ${ }^{249}$.

The Government of Kazakhstan has sought to increase foreign investment. Since 2015, Kazakhstan has been a member of the WTO and has concluded trade agreements with many countries in the region. Kazakhstan is also a member of the Eurasian Economic Union and Common Economic Zone. On 1 January 2010, it has been subject to a common import tariff for the Customs Union of Russia, Belarus and Kazakhstan, which regulates the conditions of market access for commodities. Kazakhstan has negotiated transition periods for the application of the common customs tariff rates of the Customs Union for more than 400 tariff lines. The transitional periods apply to goods of economic importance to Kazakhstan, i.e. apples, pharmaceuticals, certain synthetic polymer products (including polyurethane), wood pulp, cellulose, paper and cardboard, aluminium products (including aluminium foil and tubes), hand-held power tools, machines and apparatus for the manufacture of electronic systems, electrical circuit protection apparatus, passenger and cargo railway carriages, optical articles, cameras, measuring instruments and devices, medical instruments and appliances, and prefabricated buildings ${ }^{250}$.

Kazakhstan attracted far more foreign investment than it allocated in other countries ${ }^{251}$. It is one of the major recipients of foreign investment in the CIS countries. In June 2014, President Nursultan Nazarbayev signed tax relief legislation for foreign investment promotion, including 10-year exemption for legal persons, 8-year exemption from property tax and freezing of other taxes for a period of 10 years. In order to attract foreign investors, the income tax rate was cut from $30 \%$ to $20 \%$, and the government reduced the VAT rate to $12 \%$ in 2009. These activities increased the access of foreign investors to the Kazakhstan market and enabled the introduction of many new products in the automotive, railway, chemical and rare earth metal industries. The World Bank supported further growth in foreign investment, and the funds provided were used to build a network of roads, schools and healthcare facilities. Following the adoption of the public-private partnership law, which amended the

\footnotetext{
${ }^{249}$ В. ДОДОНОВ, Экономическое сотрудничество Казахстана с ЕС и ЕАЭС и сочиально-экономические эффекты, Алматы 2017, za: https://library.fes.de/pdf-files/bueros/kasachstan/13623.pdf (14.11.2020); Изменение подходов в привлечении инвестиций, или как инвестиционная отрасль Казахстана адаптируется к вызовам пандемии, za: https://finance.kz/articles/izmenenie_podhodov_v_privlechenii_investitsiy_ili_kak_investitsionnaya_otrasl_kaza hstana_adaptiruetsya_k_vyzovam_pandemii-4086(14.11.2020)

250 Д. Сатпав, Центрально-Азиатское сближение. Илюзия или реальный ианс?, Трансформация за кономики Казахстана, Астана, 2019, с. 327-246.
}

251 Б. Кнатов, Значение иностранных инвестиций для Республики Казахстан, za: https://journal.zakon.kz/4494768-znachenie-inostrannykh-investicijj-dlja.html (15.11.2020). 
principles of ownership protection and foreign capital attraction, foreign workforce started to be brought into the country. According to the assessment of the Ministry of Investment and Development of Kazakhstan, between May 2016 and January 2019, foreign investment in oil refineries increased by $80 \%$, in the food industry by $30 \%$ and in the machinery industry seven-fold. The main investors in Kazakhstan were the Netherlands, USA and Switzerland ${ }^{252}$.

\section{Legal basis for economic relations}

Since 1 May 2004, Poland has been a party to the Partnership and Cooperation Agreement concluded by the European Union with Kazakhstan on 12 May 1996 intended to strengthen mutual contacts, support transformation processes and promote trade and investment activities $^{253}$. On 21 December 2015, Kazakhstan signed another Enhanced Partnership and Cooperation Agreement with the European Union, consisting of nine titles. It covered issues such as general provisions, political dialogue, international cooperation, security policy, cooperation on economic development and sustainable development, activities in the area of justice, freedom, financial and technical cooperation, and the institutional framework. Overall, the parties agreed to establish and extend mutual cooperation in 29 sectors $^{254}$. The Enhanced Partnership and Cooperation Agreement (EPCA) signed in 2015 entered into force in March $2020^{255}$.

In addition, Poland has signed a number of bilateral agreements with Kazakhstan. There were 26 international agreements concluded between the Republic of Kazakhstan and the Republic of Poland, first of which were signed in the $1990 \mathrm{~s}^{256}$. In 2019, 22 were in force. Among the most important such documents is the agreement on the promotion and mutual protection of investment of 21 September 1994, where the concept of investment is defined. The parties thereto agreed to protect and promote mutual investment. The agreement specifies

\footnotetext{
252 Какие отрасли в Казахстане самые привлекательные для иностранных инвесторов, zа: https://24.kz/ru/news/economyc/item/357591-kakie-otrasli-v-kazakhstane-samye-privlekatelnye-dlyainostrannykh-investorov (15.11.2020).

${ }^{253}$ Council and Commission Decision on the conclusion of the Partnership and Cooperation Agreement between the European Communities and their Member States, of the one part, and the Republic of Kazakhstan, of the other part, OJ L $196 / 1$ of 28.07.1999

${ }^{254}$ Council Decision on the conclusion of the Enhanced Partnership and Cooperation Agreement between the European Union and its Member States, of the one part, and the Republic of Kazakhstan, of the other part, http://eur-lex.europa.eu/legal-content/PL/TXT/?uri=CELEX\%3A52016JC0026 ( 17.07.2019).

${ }^{255}$ Foreign trade figures of Kazakhstan, https://www.nordeatrade.com/fi/explore-new-market/kazakhstan/tradeprofile (17.11.2020)

256 T. Waśkiel, Polska-Kazachstan: perspektywy wspótpracy i polskie interesy w Azji Centralnej, Dyplomacja i Bezpieczeństwo 2016, nr. 1., s. 207-225.
} 
the circumstances in which a foreign investor may be expropriated, regulates the transfer of payments and sets the rules for settling disputes between the parties ${ }^{257}$.

Since 1995, the Convention on the avoidance of double taxation and prevention of tax evasion with respect to taxes on income and on capital has also been in force ${ }^{258}$. The Convention mentions the taxes to which it pertains and defines the place of residence or the seat of an enterprise, the establishment, the income from immovable property, the profits of enterprises, the international carriage of goods and the vehicles used in it, dividends, royalties, profits from the sale of assets, the professions, hired labour, remuneration of directors, the works of artists, students, lecturers, pensions and public finances. The Convention introduced equal treatment, a mutual agreement procedure and rules to avoid double taxation. The final provisions of the Convention set out the principles for the termination of agreements.

In addition, the parties have concluded an agreement on combating organised crime. In Article 1 of that agreement, the parties committed themselves to combating illegal migration, human trafficking and illegal economic activity ${ }^{259}$. Furthermore, Kazakhstan and Poland entered into agreements on international road transport ${ }^{260}$, on cooperation and mutual assistance in customs matters ${ }^{261}$, on cooperation in tourism ${ }^{262}$ and air transport ${ }^{263}$. Combating illegal migration was also addressed in detail in the readmission agreement ${ }^{264}$.

On 22 August 2016 the Presidents of Kazakhstan and Poland signed the agreement on economic cooperation between the two countries. It referred to the provisions of the Treaty on

\footnotetext{
${ }^{257}$ Agreement between the Government of the Republic of Poland and the Government of the Republic of Kazakhstan on the promotion of mutual protection of investments done at Almaty on 20 September 1994. Journal of Laws of 1995 No. 121, item 584.

${ }^{258}$ Convention between the Government of the Republic of Poland and the Government of the Republic of Kazakhstan for the Avoidance of Double Taxation and the Prevention of Fiscal Evasion with Respect to Taxes on Income and on Capital, Journal of Laws of 1995 No. 121, item 586.

259 Agreement between the Government of the Republic of Poland and the Government of the Republic of Kazakhstan on combating organised crime and other types of crime, Journal of Laws of 2005, No. 156, item 1313.

${ }^{260}$ Agreement between the Government of the Republic of Poland and the Government of the Republic of Kazakhstan on international road transport, Journal of Laws of 2001, No 46, item 749.

${ }^{261}$ Agreement between the Government of the Republic of Poland and the Government of the Republic of Kazakhstan on mutual cooperation and assistance in customs matters, Journal of Laws of 2005, No 93, item 777.

${ }^{262}$ Agreement between the Government of the Republic of Poland and the Government of the Republic of Kazakhstan on cooperation in tourism signed in Astana on 29 March 2007, Official Gazette of the Republic of Poland (M. P.) of 2008, No. 6, item 68.

263 Agreement between the Government of the Republic of Poland and the Government of the Republic of Kazakhstan on mutual cooperation on air transport signed in Warsaw, Official Gazette of the Republic of Poland (M. P.) of 2008, No. 32, item 284.

${ }^{264}$ Agreement between the Government of the Republic of Poland and the Government of the Republic of Kazakhstan on the readmission of persons, signed in Warsaw on 22 August 2016, Journal of Laws of 2017, item 1623.
} 
the Development of Friendly Relations and Cooperation between the Republic of Poland and the Republic of Kazakhstan of 27 November 1997, establishing it as the basis for the development of their relations. The Parties agreed to develop cooperation in the following areas: 1/ economy and entrepreneurship; 2/ trade and investment; 3/ energy; 4/ science, technology and innovation; 5/ space research; 6/ finance; 7/ transport and communication; 8/ ecology and environmental protection; 9/ agriculture; 10/ tourism; 11/ education ${ }^{265}$.

The Government Statement signed by the Ministers of Foreign Affairs of Poland and Kazakhstan upheld the validity of the Multilateral Convention to Implement Tax Treaty Related Measures done in Paris on 24 November 2016 and its applicability in the implementation of the Polish-Kazakh relations in the agreement on the avoidance of double taxation and prevention of tax evasion with respect to taxes on income and on capital of 21 September $1994^{266}$.

\section{Trade and investment}

Poland and Kazakhstan have been trading since the establishment of the countries' mutual relations. The relevant trade figures are listed in Table 2.

Tabela2. Kazakhstan's exports to and imports from Poland in 1995-2018*

\begin{tabular}{|l|l|l|l|l|c|}
\hline \multicolumn{1}{|c|}{ Year } & Export (USD) & \% of exports & Import (USD) & \% of imports & Balance \\
\hline 1995 & $37,218.88$ & 0.71 & $19,808.91$ & 0.52 & $17,699.98$ \\
\hline 1996 & $21,420.38$ & 0.00 & $41,858.53$ & 0.01 & $-19,093.29$ \\
\hline 1997 & $27,834.79$ & 0.01 & $40,868.01$ & 0.00 & $-13,033.22$ \\
\hline 1998 & $41,481.59$ & 0.15 & $45,646.26$ & 0.01 & $-4,082.67$ \\
\hline 1999 & $93,836.39$ & 1.60 & $62,603.63$ & 1.72 & $31,272.75$ \\
\hline 2000 & $56,626.10$ & 0.65 & $58,611.40$ & 1.18 & $11,985.30$ \\
\hline 2001 & $164,156.70$ & 1.93 & $61,349.90$ & 0.98 & $102,806.80$ \\
\hline 2002 & $320,481.50$ & 3.32 & $74,655.40$ & 1.13 & $245,826.10$ \\
\hline 2003 & $200,965.00$ & 1.56 & $117,159.90$ & 1.39 & $83,805.10$ \\
\hline 2004 & $188,569.06$ & 0.94 & $169,750.79$ & 1.33 & $18,818.27$ \\
\hline 2005 & $367,590.30$ & 0.02 & $197,124.66$ & 0.18 & $170,465.72$ \\
\hline 2006 & $204,445.01$ & 0.18 & $303,403.37$ & 0.25 & $-98,957.46$ \\
\hline 2007 & $256,954.48$ & 0.10 & $396,988.85$ & 0.17 & $-140,034.37$ \\
\hline 2008 & $461,546.03$ & 0.65 & $426,454.44$ & 1.13 & $35,130.59$ \\
\hline
\end{tabular}

\footnotetext{
${ }^{265}$ Declaration https://www.prezydent.pl/aktualnosci/wydarzenia/art,360,deklaracja-o-wspolpracy-gospodarczejmiedzy-rzeczapospolita-polska-i-republika-kazachstanu.html (17.11.2020).

266 The Government Statement of 5 August 2020 on the validity of the multilateral Convention implementing Treaty tax law measures to prevent erosion of the tax base and profit shifting, done at Paris on 24 November 2016, applicable to the relations between the Republic of Poland and the Republic of Kazakhstan, and its application in the implementation of the provisions of the Convention between the Government of the Republic of Poland and the Government of the Republic of Kazakhstan on the avoidance of double taxation and the prevention of tax evasion in respect of taxes on income and on capital, done at Almaty on 21 September 1994, Journal of Laws of 2020, item 1650.
} 


\begin{tabular}{|l|l|l|l|l|c|}
\hline 2009 & $835,772.58$ & 0.90 & $421,581.09$ & 0.41 & $414,211.49$ \\
\hline 2010 & $1,215,520.70$ & 2.12 & $376,613.27$ & 1.57 & $838,907.43$ \\
\hline 2011 & $1,305,533.68$ & 1.48 & $391,279.71$ & 1.03 & $914,077.98$ \\
\hline 2012 & $1,631,970.70$ & 1.77 & $470,374.90$ & 1.06 & $1,161,599.80$ \\
\hline 2013 & $679,496.75$ & 0.80 & $507,910.30$ & 1.04 & $171,586.46$ \\
\hline 2014 & $595,684.18$ & 0.75 & $429,327.79$ & 1.04 & $166,356.40$ \\
\hline 2015 & $789,188.43$ & 1.72 & $340,546.04$ & 1.11 & $448,642.39$ \\
\hline 2016 & $504,954.31$ & 1.37 & $254,317.02$ & 1.01 & $250,637.29$ \\
\hline 2017 & $574,333.48$ & 1.18 & $327,355.73$ & 1.11 & $246,097.75$ \\
\hline 2018 & $891,233.65$ & 1.46 & $283,521.88$ & 0.84 & $607,711.76$ \\
\hline
\end{tabular}

Source: own compilation based on: Kazakhstan Exports to Poland; Imports from Poland https://wits.worldbank.org/CountryProfile/en/Country/KAZ/Year/2017/TradeFlow/EXPIMP/Partner/POL/Produ ct/all-groups_(17.11.2020)

* data up to 2018

Kazakhstan generally had a positive balance of trade with Poland, with the exception of the periods 1996-1998 and 2006-2007. The main product groups exported by Kazakhstan to Poland include fuels, metals, intermediate goods, chemicals, vegetables, livestock, stone and glass, and raw materials. Meanwhile, Poland's exports to Kazakhstan included the aviation and shipbuilding industry products (including cargo ships, floating structures), mining machinery, construction machinery, engine parts, electric power control equipment and electric cables, filtration equipment, sorting machines, refrigeration equipment, lifting equipment, trailers and semi-trailers, grain-handling equipment, gas turbines, some medical devices and protective devices, as well as air conditioners, household appliances (ovens, hobs) and certain agricultural machinery and food processing equipment. In the 2010s there was an increase in the export from Poland of: medicines, cosmetics (shampoos, creams, deodorants, liquid soap, shaving products, toothpaste), washing and cleaning agents, conveyor belts (mainly for mining) and plastic articles. At the same time, there was a decline in the supplies of, inter alia, building chemicals, paints and varnishes, produce, $(-13.1 \%$, mainly of apples and sugar), as well as of certain meat products (beef) and potato starch. The exports of frozen food, potatoes, mushrooms, sugar syrups, sauces and condiments, animal feed and frozen vegetables increased during that period. Furthermore, in 2018 there was a decrease in the Polish exports of furniture, wood, paper products, light industry products, refrigerators/freezers, prosthetics and wallpaper. Meanwhile, the supplies of hygiene and skincare products for women and ceramic products increased. The trade and investment policy adopted by Kazakhstan did not create specific restrictions on access to the domestic market for foreign operators. As regards investment policies, Kazakhstan's government pursued a policy of equal treatment of domestic and foreign investors. However, in order to 
encourage foreign enterprises to invest in Kazakhstan, it was established that foreign investors could be offer special concessions and preferences within special economic zones ${ }^{267}$.

Poland's direct investment in Kazakhstan represents only a small percentage of total foreign direct investment.

Table 3. Inflow of foreign investments to Kazakhstan

\begin{tabular}{|c|c|c|}
\hline Year & $\begin{array}{l}\text { Kazakhstan } \\
\text { Overall foreign investments }\end{array}$ & $\begin{array}{l}\text { Polish investments } \\
\text { in million USD }\end{array}$ \\
\hline 1992 & 100.0 & 0 \\
\hline 1993 & $1,271.4$ & 0 \\
\hline 1994 & 659.7 & 0 \\
\hline 1995 & 964.3 & 0 \\
\hline 1996 & $1,136.9$ & 0 \\
\hline 1997 & $1,321.9$ & 0 \\
\hline 1998 & $1,160.9$ & 0 \\
\hline 1999 & $1,437.7$ & 0 \\
\hline 2000 & $1,282.5$ & 0 \\
\hline 2001 & $2,835.0$ & 0 \\
\hline 2002 & $2,590.2$ & 0 \\
\hline 2003 & $2,092.0$ & 0 \\
\hline 2004 & $4,157.2$ & 0 \\
\hline 2005 & $1,971.2$ & 6.7 \\
\hline 2006 & $6,278.2$ & 12.0 \\
\hline 2007 & $11,119.0$ & 25.2 \\
\hline 2008 & $14,321.8$ & 18.9 \\
\hline 2009 & $13,242.5$ & 14.2 \\
\hline 2010 & $11,550.7$ & 9.3 \\
\hline 2011 & $13,973.1$ & 15.9 \\
\hline 2012 & $13,337.0$ & 16.7 \\
\hline 2013 & $10,321.0$ & 19.1 \\
\hline 2014 & $8,405.9$ & 42.8 \\
\hline 2015 & $4,012.1$ & 7.1 \\
\hline 2016 & $8,511.5$ & 12.1 \\
\hline 2017 & $4,669.3$ & \\
\hline 2018 & $3,816.6$ & \\
\hline & & \\
\hline
\end{tabular}

Source: own compilation based on: Gross inflow of direct investment in Kazakhstan from foreign direct investors: breakdown by countries, http://unctad.org/en/Pages/DIAE/World\%20Investment\%20Report/AnnexTables.aspx (10.11.2020).

Poland's weak position as an investor in Kazakhstan was due to the fierce competition in the markets of the Central Asian countries. The major foreign players in that region come from China, Germany, the Russian Federation, the United States, the United Kingdom, 267 Specjalne strefy ekonomiczne w Razachstanu za: https://kazakhstan.trade.gov.pl/pl/kazachstan/inwestycje/167124,specjalne-strefy-ekonomiczne-kazachstanu.html (17.11.2020). 
Turkey and France ${ }^{268}$. The priority investment areas in Kazakhstan have been the chemical, petrochemical and mining industries. This is where the majority of foreign investments in Kazakhstan were located ${ }^{269}$. In the period investigated, the largest investment project was the purchase by Polpharma of a pharmaceutical company Chimfarm, as well as the construction of two production facilities of Selena. Other entities that made investments in Kazakhstan include Eko-Export, Pronair, APS, Energia, Exallo Drilling, Petrolinvest, and Ulma Construction. In 2016 Eko-Eksport opened a microsphere factory in Astana. In 2016 there were 190 economic entities with Polish capital participation of various ownership forms registered in Kazakhstan ${ }^{270}$. At that time, there was a demand for large Polish companies from such sectors as waste management, petrochemical, mining and road construction, and remediation of chemical landfill sites ${ }^{271}$.

In 2019, there were already 200 companies with Polish capital registered in Kazakhstan, but only 100 of them had commenced business activities in the pharmaceutical sector (manufacture of medicines), the construction sector (production of construction chemicals), as well as in the sectors of energy, agricultural machinery, transport infrastructure and agri-food industry ${ }^{272}$.

The prospective areas of trade and investment cooperation between Polish and Kazakh companies include: 1/ construction (including building materials); 2/ agriculture establishment of fruit orchards, construction of grain silos, warehouses, cold stores, greenhouses); 3/ agri-food processing 4/ IT\&ICT (the "Digital Kazakhstan" state programme was launched in 2017). In addition, the prospective directions for the development of cooperation include: in the sphere of trade - mining, road construction and agricultural machinery, transport and passenger vehicles, medical equipment, shipbuilding, building materials, pharmaceuticals and cosmetics, agricultural products, furniture etc. In the area of investment, there are opportunities to develop cooperation in the chemical and mining and agricultural machinery sectors, as well as in energy, environmental, logistics and transport

\footnotetext{
${ }^{268}$ В. Додонов, Иностранные инвестиции в Казахстан: прагматичная оченка масштабов и влияния на экономическое развитие, Трансформация экономики Казахстана, Астана, 2019, s. 241-260.

${ }^{269}$ Ibidem.

${ }^{270}$ W jakie innowacje inwestuja polskie firmy w Kazachstanie, za: https://www.money.pl/gospodarka/w-jakieinnowacje-inwestuja-polskie-firmy-6482831823612033a.html (19.11.2020).

271 Poszukiwanie inwestycji dla projektu oczyszczania składowisk technicznych, za: https://kazakhstan.trade.gov.pl/pl/kazachstan/inwestycje/212661,poszukiwanie-inwestycji-dla-projektuoczyszczania-skladowisk-technicznych.html (19.11.2020)

272 Polskie firmy na ruszaja podbój Kazachstanu, za: https://www.polskieradio24.pl/42/273/Artykul/2199511,Polskie-firmy-ruszaja-na-podboj-Kazachstanu (18.11.2020)
} 
projects. The implementation of investment projects in Kazakhstan also offers opportunities for the supply to third country markets (e.g. EAEU, Central Asia, China).

According to Polish entrepreneurs, the major obstacles to developing economic cooperation include the Kazakhstan's visa system, involving lengthy and complicated procedures for obtaining entry visas. There are also problems with obtaining work permits and with the licensing system ${ }^{273}$.

\section{Efforts of the Polish-Kazakh Chamber of Commerce and Industry}

Poland began diplomatic and trade cooperation with Kazakhstan in 1992, but it was only under the Economic Cooperation Agreement between Poland and Kazakhstan signed in July 2005 that the Polish-Kazakh Intergovernmental Commission for Economic Cooperation was established. Article 5 of the Agreement stipulates that the Commission's tasks include the assessment of economic cooperation, identification of problems that restrict cooperation, preparation of proposals for further cooperation and dispute resolution. The Commission is composed of two sections: Polish and Kazakh, which are authorised to establish working groups and define their tasks. The Commission's meetings are to be held at least once a year, alternately in Poland and in Kazakhstan. An extraordinary meeting of the Commission or a meeting of the Presidents may be convened at the initiative of each of the Presidents ${ }^{274}$.

During its second meeting (on 2 October 2009) the Polish-Kazakh Intergovernmental Commission for Economic Cooperation made a decision to promote the list of investment projects submitted by Kazakhstan concerning financing and implementation by Polish companies (44 projects) and agreed the measures intended to solve the problems of Polish companies in the Kazakh market, i.e. assistance in obtaining work permits for Polish specialists, addressing the insufficient protection of intellectual property rights, reactivation of the working groups for cooperation in the sectors of oil and gas, tourism and infrastructure, undertaking scientific and advisory cooperation in the fields of oil and gas engineering, maritime education, agricultural consulting, training in tourism, training in the protection and conservation of monuments, in small and medium-sized enterprises, as well as in the operation of pension funds, conducting talks with veterinary services to regulate the

\footnotetext{
273 Informacje dotyczące sytuacji gospodarczej $w$ Kazachstanie, za: https://www.google.com/search?q=trudnoaci+polskich+firm+w+kazachstanie\&rlz=1C1EJFA_enPL716PL716\& $\mathrm{oq}=$ trudnoaci + polskich + firm $+\mathrm{w}+$ kazachstanie $+\&$ aqs $=$ chrome.. $69 \mathrm{i} 57 \mathrm{j} 33 \mathrm{i} 22 \mathrm{i} 29 \mathrm{i} 30.9188 \mathrm{j} 1 \mathrm{j} 7 \&$ sourceid $=$ chrome $\& \mathrm{i}$ $\mathrm{e}=\mathrm{UTF}-8$ (18.11.2020).

${ }^{274}$ Agreement between the Government of the Republic of Poland and the Government of the Republic of Kazakhstan on economic cooperation, done at Astana on 6 July 2005, Official Gazette of the Republic of Poland 2006, $\operatorname{nr} 13$, s. 173.
} 
requirements for beef and livestock export from Poland to Kazakhstan and signing a Memorandum of Cooperation in veterinary medicine. The Commission meeting was accompanied by the signing of the Memorandum of Cooperation between PARP and the Kazakhstan Enterprise Development Fund (DAMU). The exhibition "Designed in Poland" was also opened. More than 70 representatives of Polish business and 80 representatives of Kazakh business took part in the Poland-Kazakhstan Economic Forum (2 October 2009). During the Forum, a number of documents relating to the cooperation between the selfregulatory organisations of the two countries were signed: 1/ Memorandum of cooperation between the Polish-Kazakh Chamber of Commerce and Industry and the Kazakhstan Chamber of Commerce and Industry and 2/ Memorandum of Cooperation between the Confederation of Polish Employers and the Confederation of Kazakh Employers. On 21 June 2011, the Poland-Kazakhstan Business Forum was held in the headquarters of Bank Gospodarstwa Krajowego in Warsaw. The Forum was an accompanying event to the third meeting of the Polish-Kazakh Intergovernmental Commission for Economic Cooperation, which summarised the achievements made in trade and investment ${ }^{275}$.

During the 4th meeting of the Polish-Kazakh Intergovernmental Commission for Economic Cooperation, held in Astana, the capital of Kazakhstan, on 17 September 2013, it was decided to put forward proposals for regional cooperation. The first Polish-Kazakh Forum of Regions was scheduled for early 2014. This proposal was presented in 2012 by the Kazakh regional governments $^{276}$.

Table 4. Proposals for inter-regional cooperation

\begin{tabular}{|l|c|l|}
\hline No. & $\begin{array}{c}\text { Name of akimat } \\
\text { (local } \\
\text { government) }\end{array}$ & \multicolumn{1}{c|}{ Proposals the local governments } \\
\hline 1 & $\begin{array}{c}\text { Almaty } \\
\text { Akimat }\end{array}$ & $\begin{array}{l}\text { 1. Attracting Polish investors to the following projects: "Construction of a Light } \\
\text { Rail Transport Line", "Industrialization of the Alatau District in Almaty", "SEZ } \\
\text { Information Technology Park", "Construction of the "Kok Zhailau" Ski Complex. } \\
\text { 2. Investment in materials science and processing, biotechnology, } \\
\text { nanotechnology, space technologies, etc., to ensure the development of priority } \\
\text { industries. } \\
\text { 3. Cooperation of experts and sharing experiences in the use of modern medical } \\
\text { technologies. } \\
\text { 4. Joint conferences of leading medical specialists from both countries. }\end{array}$ \\
\hline
\end{tabular}

275 Bank Gospodarstwa Krajowego gospodarzem Forum Biznesu Polska-Kazachstan, za: https://www.bgk.pl/aktualnosc/bank-gospodarstwa-krajowego-gospodarzem-forum-biznesu-polskakazachstan/(19.11.2020).

276 Nowy impuls współpracy Polsko- Kazachstańskiej, za: http://www.polishmarket.com.pl/wy-impuls-wewspolpracy-polsko-kazachstanskiej/ (19.11.2020). 


\begin{tabular}{|c|c|c|}
\hline & & $\begin{array}{l}\text { 5. As part of medical assistance, treatment of seriously ill patients from Almaty in } \\
\text { leading Polish university hospitals and medical centres. } \\
\text { 6. Organisation of concerts of creative groups, exhibitions of museum and library } \\
\text { collections, forums on cultural heritage. } \\
\text { 7. Exchange of representatives of NGOs, political parties and trade unions to } \\
\text { share experiences in the area of cooperation with civil society institutions } \\
\text { 8. Learning about the problems of parties and organisations, meetings with } \\
\text { political party leaders. } \\
\text { 9. Learning about new ways of combating religious extremism, migration } \\
\text { regulation and youth education. }\end{array}$ \\
\hline 2. & $\begin{array}{l}\text { Pavlodar Region } \\
\text { Akimat }\end{array}$ & $\begin{array}{l}\text { Announcements in the mass media about the cooperation between Kazakhstan and } \\
\text { Poland in the field of culture and economy. Screenings of Polish films in Pavlodar } \\
\text { cinemas. }\end{array}$ \\
\hline 3. & $\begin{array}{ll}\text { Aktobe } & \text { Region } \\
\text { Akimat } & \end{array}$ & $\begin{array}{l}\text { Organisation of the Polish National Exhibition in Aktobe in 2013, with the } \\
\text { participation of representatives of Polish companies. }\end{array}$ \\
\hline 4. & $\begin{array}{ll}\text { Atyrau } & \text { Region } \\
\text { Akimat } & \end{array}$ & $\begin{array}{l}\text { 1. Development of the petrochemical industry, construction of machinery for } \\
\text { the oil and gas industry, processing industry and construction, development of } \\
\text { alternative energy sources; } \\
\text { Production and sale of agricultural products, development of animal } \\
\text { husbandry and crop research, establishment of joint undertakings in the energy } \\
\text { sector; } \\
\text { Within the framework of trade and economic relations - proposal to organize a } \\
\text { business forum and exhibitions in the Atyrau region and in Poland. }\end{array}$ \\
\hline 5. & $\begin{array}{ll}\text { Akmola Region } \\
\text { Akimat }\end{array}$ & Establishment of a joint undertaking in the field of fur farming \\
\hline 6. & $\begin{array}{l}\text { South Kazakhstan } \\
\text { Region Akimat }\end{array}$ & $\begin{array}{l}\text { Attracting investors to implement a project for the construction of a ski resort in } \\
\text { the Kaskas gorge, in the Tolebeya district of the South Kazakhstan region }\end{array}$ \\
\hline 7. & $\begin{array}{l}\text { North Kazakhstan } \\
\text { Region Akimat }\end{array}$ & $\begin{array}{l}\text { Organisation of cultural exhibitions, international exchange of students to learn } \\
\text { the language, conducting online workshops on applied and folk arts, and monthly } \\
\text { teachers' conferences on various topics. }\end{array}$ \\
\hline
\end{tabular}

Source: own compilation based on: Propozycja wspótpracy gospodarczej z Kazachstanem, https://pracodawcypomorza.pl/2012/10/28/propozycja-wspolpracy-gospodarczej-z-kazachstanem/(20.11.2020)

The proposals submitted by the regional governments were published on the websites of the respective voivodeships and promoted by the ambassador of Kazakhstan ${ }^{277}$.

At the Commission's 7th meeting in April 2016 in Warsaw the pro-investment policy of Kazakhstan was presented. Furthermore, the objectives of the Polish investor support programme in that country were outlined ${ }^{278}$. As a result of these arrangements, a direct scheduled flight between Warsaw and Astana organised by LOT Polish Airlines was launched on 29 May 2017. The parties also emphasised the rapid growth in the trade in goods, which

277 Ambasador Kazachstanu $\mathrm{z} \quad$ wizytą $\mathrm{u}$ Marszałka,

https://www.malopolska.pl/aktualnosci/wspolpraca/ambasador-kazachstanu-z-wizyta-u-marszalka-2?size=sizebig (20.11.2020).

278 Polityka ekonomiczna Kazachstanu $14 \quad$ kwietnia 2016 za: https://www.lazarski.pl/pl/aktualnosci/aktualnosc/konferencja-polityka-ekonomiczna-kazachstanu-14-kwietnia2016/ (20.11.2020). 
was around USD 1 billion in 2017. During the 8th meeting of the Commission on 19 June 2018 , the Kazakh party announced that the veterinary services had lifted the prohibition on the import into the territory of Kazakhstan of pork products treated to ensure the destruction of ASF virus. However, pork deliveries to Kazakhstan had to be made so as to bypass the other members of the Eurasian Economic Union ${ }^{279}$. The Commission meeting was accompanied by the Polish-Kazakh Economic Forum, where cooperation in the field of transport and logistics was discussed, including railway container services, certification of railway products, and air services. It was agreed to sign a Bilateral Cooperation Roadmap in the field of transport and a Memorandum on the Information Partnership between the International Information Agency "Kazinform" and the Polish Information Agency. Taking into account the 34,000 Polish diaspora in Kazakhstan, the Parties agreed to exchange information about their countries via the "Kazakh TV" television station. The participants emphasised that there were no major problems in Polish-Kazakh relations. The meeting was an opportunity to exchange views on a number of topical issues of the international agenda, Central Asia and the cooperation of States in the context of the implementation of the "One Belt - One Road" initiative ${ }^{280}$.

\section{Summary}

Poland's economic relations with Kazakhstan were established in the 1990s. Until the end of 2019, they were governed by 22 agreements, the most important of which were the agreement on the promotion and mutual protection of investments, the convention on avoiding double taxation and prevention of tax evasion with respect to taxes on income and on capital, and the declaration on economic cooperation between Poland and Kazakhstan.

Generally, Kazakhstan had a positive balance of trade with Poland, with the exception of the periods 1996-1998 and 2006-2007. In 1995, the export to Poland accounted for 0.71\% and in 2018 for $1.46 \%$ of Kazakhstan's overall exports. As for the imports, the trade with Poland represented $0.52 \%$ of the Kazakhstan's total imports in 1995 and $0.84 \%$ in 2018. The main product groups exported to Poland were fuels, metals, intermediate products, chemicals, vegetables, animals, stone and glass, and raw materials. Meanwhile, Poland's imports to Kazakhstan included the aviation and shipbuilding industry products, mining machinery,

\footnotetext{
${ }^{279}$ Zniesienie zakazu ASF przez Kazachstan, za: https://www.cenyrolnicze.pl/wiadomosci/rynki-rolne/trzodachlewna/12627-zniesienie-zakazu-asf-przez-kazachstan (21.11.2020).

280 8th Meeting of the Polish-Kazakh Intergovernmental Commission for Economic Cooperation in Astana , za: https://www.paih.gov.pl/20180526/viii_posiedzenie_polsko_kazachstanskiej_komisji_miedzyrzadowej_ds_wspo lpracy_gospodarczej (21.11.2020)
} 
construction machinery, engine parts, electric power control equipment, sorting machines, refrigeration equipment, lifting equipment, trailers and semi-trailers, grain-handling equipment, gas turbines, some medical devices and protective devices, as well as air conditioners, household appliances (ovens, hobs) and certain agricultural machinery and food processing equipment. Poland's foreign investments in Kazakhstan were not very impressive; the first investment projects were not launched until 2005. In 2019, approximately 200 companies with Polish capital were registered in Kazakhstan, 100 of which were active. The main area of activity of Polish companies in Kazakhstan is the oil and gas industry, including oil and natural gas exploration. Polish companies also operated in the machinery and transport equipment industry, plastic manufacturing, construction services and household chemicals production.

The Polish-Kazakh Intergovernmental Commission for Economic Cooperation commenced its efforts in 2005. By 2019, eight meetings of the Commission had been held, having addressed such matters as the promotion of investment projects and measures to solve the problems of Polish companies in the Kazakh market. The parties also presented a proposal for regional cooperation. The Commission's efforts had only a slight reinforcing effect on the cooperation between the partners.

\section{Streszczenie:}

Przed 2019 rokiem stosunki gospodarcze między Polską a Kazachstanem regulowały 22 umowy międzynarodowe. Polska handluje $\mathrm{z}$ Kazachstanem od lat 90. Generalnie Kazachstan miał dodatnie saldo w handlu z Polską, z wyjątkiem okresów 1996-1998 i 20062007. Polskie inwestycje zagraniczne w Kazachstanie nie były zbyt imponujące; pierwsze inwestycje rozpoczęto dopiero w 2005 r. W 2019 r. w Kazachstanie zarejestrowano około 200 spółek z polskim kapitałem, ale tylko $100 \mathrm{z}$ nich rozpoczęło działalność gospodarczą. W latach 2005-2019 odbyło się osiem posiedzeń Polsko-Kazachskiej Międzyrządowej Komisji ds. Współpracy Gospodarczej. Ich uczestnicy dyskutowali o projektach inwestycyjnych, strategiach rozwoju handlu oraz propozycjach współpracy regionalnej.

\section{Słowa kluczowe:}

współpraca gospodarcza, Polska, Kazachstan, handel, inwestycje

\section{Key words:}

economic cooperation, Poland, Kazakhstan, trade, investment 


\section{Bibliografia:}

1. Bank Gospodarstwa Krajowego gospodarzem Forum Biznesu Polska-Kazachstan, https://www.bgk.pl/aktualnosc/bank-gospodarstwa-krajowego-gospodarzem-forumbiznesu-polska-kazachstan/(19.11.2020).

2. Council and Commission Decision on the conclusion of the Partnership and Cooperation Agreement between the European Communities and their Member States, of the one part, and the Republic of Kazakhstan, of the other part, OJ L 196/1 of 28.07.1999

3. Council Decision on the conclusion of the Enhanced Partnership and Cooperation Agreement between the European Union and its Member States, of the one part, and the Republic of Kazakhstan, of the other part , http://eur-lex.europa.eu/legalcontent/PL/TXT/?uri=CELEX\%3A52016JC0026 (17.07.2019).

4. GDP - composition by sector of origin, https://www.cia.gov/library/publications/theworld-factbook/geos/pl.html (13.11.2020).

5. В. ДОДОНОВ, Экономическое сотрудничество Казахстана с ЕС и ЕАЭС и социально-экономические эффекты , Алматы 2017, https://library.fes.de/pdffiles/bueros/kasachstan/13623.pdf (14.11.2020).

6. Додонов, В., Иностранные инвестиции в Казахстан: прагматичная оценка масштабов и влияния на экономическое развитие, Трансформация экономики Казахстана, Астана, 2019, с. 241-260

7. Declaration https://www.prezydent.pl/aktualnosci/wydarzenia/art,360,deklaracja-owspolpracy-gospodarczej-miedzy-rzeczapospolita-polska-i-republikakazachstanu.html (17.11.2020)

8. Foreign trade figures of Kazakhstan, https://www.nordeatrade.com/fi/explore-newmarket/kazakhstan/trade-profile (17.11.2020).

9. Gross inflow of direct investment in Kazakhstan from foreign direct investors: breakdown countries, http://unctad.org/en/Pages/DIAE/World\%20Investment\%20Report/AnnexTables.aspx (10.11.2020).

10. Information on the economic situation in Kazakhstan , https://www.google.com/search? q=trudnoaci + polskich + firm + w + kazachstanie\&rlz=1C 1EJFA_enPL716PL716\&oq $=$ trudnoaci + polskich + firm $+w+$ kazachstanie $+\& a q s=$ chrom e..69i57j33i22i29i30.9188j1j7\&sourceid=chrome\&ie=UTF-8 (18.11.2020).

11. Изменение подходов в привлечении инвестиций, или как инвестиционная отрасль Казахстана адаптируется к вызовам пандемии, https://finance.kz/articles/izmenenie_podhodov_v_privlechenii_investitsiy_ili_kak_in vestitsionnaya_otrasl_kazahstana_adaptiruetsya_k_vyzovam_pandemii-4086 (14.11.2020).

12. Какие отрасли в Казахстане самые привлекательные для иностранных инвесторов, $\quad$ https://24.kz/ru/news/economyc/item/357591-kakie-otrasli-vkazakhstane-samye-privlekatelnye-dlya-inostrannykh-investorov (15.11.2020).

13. Convention between the Government of the Republic of Poland and the Government of the Republic of Kazakhstan for the Avoidance of Double Taxation and the Prevention of Fiscal Evasion with Respect to Taxes on Income and on Capital, Journal of Laws of 1995 No. 121, item 586. 
14. Кнатов, Б., Значение иностранных инвестиций для Республики Казахстан, https://journal.zakon.kz/4494768-znachenie-inostrannykh-investicijj-dlja.html (15.11.2020).

15. Kazakhstan Among World's Top 30 Economies in Ease of Doing Business, https://www.worldbank.org/en/news/press-release/2018/10/31/kazakhstan-amongworlds-top-30-economies-in-ease-of-doing-business (10.11.2020)

16. Kazakhstan Exports to Poland; Imports from Poland https://wits.worldbank.org/CountryProfile/en/Country/KAZ/Year/2017/TradeFlow/EX PIMP/Partner/POL/Prodet/all-groups_(17.11.2020).

17. Nowy impuls we współpracy Polsko-Kazachstańskiej, http://www.polishmarket.com.pl/wy-impuls-we-wspolpracy-polsko-kazachstanskiej/ (19.11.2020).

18. The Government Statement of 5 August 2020 on the validity of the multilateral Convention implementing Treaty tax law measures to prevent erosion of the tax base and profit shifting, done at Paris on 24 November 2016, applicable to the relations between the Republic of Poland and the Republic of Kazakhstan, and its application in the implementation of the provisions of the Convention between the Government of the Republic of Poland and the Government of the Republic of Kazakhstan on the avoidance of double taxation and the prevention of tax evasion in respect of taxes on income and on capital, done at Almaty on 21 September 1994, Journal of Laws of 2020, item 1650.

19. VIII Posiedzenie Polsko-Kazachstańskiej Komisji Międzyrządowej ds. Współpracy Gospodarczej $\mathrm{W}$

Astanie, https://www.paih.gov.pl/20180526/viii_posiedzenie_polsko_kazachstanskiej_komisji_ miedzyrzadowej_ds_wspolpracy_gospodarczej (21.11.2020).

20. Polityka ekonomiczna Kazachstanu $14 \quad$ kwietnia 2016 https://www.lazarski.pl/pl/aktualnosci/aktualnosc/konferencja-polityka-ekonomicznakazachstanu-14-kwietnia-2016/ (20.11.2020).

21. Poszukiwanie inwestycji dla projektu oczyszczania składowisk technicznych, https://kazakhstan.trade.gov.pl/pl/kazachstan/inwestycje/212661,poszukiwanieinwestycji-dla-projektu-oczyszczania-skladowisk-technicznych.html (19.11.2020)

22. Polskie firmy ruszają na podbój Kazachstanu, https://www.polskieradio24.pl/42/273/Artykul/2199511,Polskie-firmy-ruszaja-napodboj-Kazachstanu (18.11.2020)

23. Propozycja współpracy gospodarczej z Kazachstanem, https://pracodawcypomorza.pl/2012/10/28/propozycja-wspolpracy-gospodarczej-zkazachstanem/

24. Д. Сатпав, Центрально-Азиатское сближение. Илюзия или реальный шанс?, Трансформация за кономики Казахстана, Астана, 2019, с. 327-246.

25. Specjalne strefy ekonomiczne w Republice Kazachstanu https://kazakhstan.trade.gov.pl/pl/kazachstan/inwestycje/167124,specjalne-strefyekonomiczne-kazachstanu.html 17.11.2020). 
26. Agreement between the Government of the Republic of Poland and the Government of the Republic of Kazakhstan on economic cooperation, done at Astana on 6 July 2005, Official Gazette of the Republic of Poland (M. P.) 2006, No.13, item 173.

27. Agreement between the Government of the Republic of Poland and the Government of the Republic of Kazakhstan on combating organised crime and other types of crime, Journal of Laws of 2005, No. 156, item 1313.

28. Agreement between the Government of the Republic of Poland and the Government of the Republic of Kazakhstan on international road transport, Journal of Laws of 2001, No 46, item 749.

29. Agreement between the Government of the Republic of Poland and the Government of the Republic of Kazakhstan on mutual cooperation and assistance in customs matters, Journal of Laws of 2005, No 93, item 777.

30. Agreement between the Government of the Republic of Poland and the Government of the Republic of Kazakhstan on cooperation in tourism signed in Astana on 29 March 2007, Official Gazette of the Republic of Poland (M. P.) of 2008, No. 6, item 68.

31. Agreement between the Government of the Republic of Poland and the Government of the Republic of Kazakhstan on mutual cooperation on air transport signed in Warsaw, Official Gazette of the Republic of Poland (M. P.) of 2008, No. 32, item 284.

32. Agreement between the Government of the Republic of Poland and the Government of the Republic of Kazakhstan on the readmission of persons, signed in Warsaw on 22 August 2016, Journal of Laws of 2017, item 1623.

33. Agreement between the Government of the Republic of Poland and the Government of the Republic of Kazakhstan on the promotion of mutual protection of investments done at Almaty on 20 September 1994. Journal of Laws of 1995 No 121, item 584.

34. Waśkiel, T., Polska- Kazachstan: perspektywy współpracy i polskie interesy w Azji Centralnej, Dyplomacja i Bezpieczeństwo 2016, No. 1 pp. 207-225.

35. W jakie innowacje inwestują polskie firmy w Kazachstanie, https://www.money.pl/gospodarka/w-jakie-innowacje-inwestuja-polskie-firmy6482831823612033a.html (19.11.2020).

36. Zniesienie zakazu ASF przez Kazachstan, https://www.cenyrolnicze.pl/wiadomosci/rynki-rolne/trzoda-chlewna/12627zniesienie-zakazu-asf-przez-kazachstan (21.11.2020). 